\title{
The Exploration of Local Knowledge on Ethnomedicine in Traditional Healing Practices at Enggano Island Bengkulu Province
}

\author{
Daisy Novira $^{1 *} \quad$ Lismaningsih $^{2} \quad$ Tamrin Bangsu $^{3}$ \\ 1.Nursing Department of Health Polytechnic Ministry of Health Bengkulu \\ 2.Health Promotion Department of Health Polytechnic Ministry of Health Bengkulu \\ 3.Social Welfare Program of Social and Political Science Faculty University of Bengkulu
}

\begin{abstract}
Regulation of Minister of Health No. 9 of 2016 concerning the efforts to develop health through self-care utilization of family herbal plants and cultivation and processing skills provides an opportunity to explore the community local wisdom to use herbal plants. Self-care health of traditional healing is an effort to maintain and improve health and prevent and overcome minor health problems experienced by individuals, families, groups and communities by utilizing family herbal plants.Based on Silalahi's research (2016) Indonesia has 25,000-30,000 species of plants and there are 300-700 ethnic groups who use local plants for various purposes, one of which is for medical treatment. Utilization of local plants is usually passed from mouth to mouth and hereditary so that increase the potential for degradation. The results of the exploration of LIPI (Indonesian Institute of Science) researchers in 2015 revealed that Enggano island is rich in diversity of flora and fauna that are important to preserve. There are more than 16 candidates for new types of flora and fauna which are likely to be typical flora and fauna of Enggano that cannot be found elsewhere. The endemic biodiversity at Enggano island has not yet been fully explored by researchers. The great efficacy of plants for traditional medicine used by the people of Enggano island still needs further study. This research aims to explore the local wisdom on ethnomedicine in the practice of traditional healing in Enggano Island. The research would be carried out at Enggano island which includes 6 (six) villages namely Kahyapu, Malakoni, Kaana, Apoho, Meok and Banjarsari villages. This study used a qualitative method with an ethnographic approach to data collection through observation, in-depth interviews and documentation studies. Data analysis used two approaches namely qualitative by using ethnographic and quantitative analysis by measuring the index cultural significance. The results showed that the Enggano community utilized local plants for medical treatment as well as for maintaining health or stamina. Subang-subang leaves had the highest ICS score of 30 and Tujuh Langit leaves had the lowest score of 1.
\end{abstract}

Keywords: herbal plants, ethnomedicine, index cultural significance

DOI: $10.7176 /$ RHSS/10-24-12

Publication date: December $31^{\text {st }} 2020$

\section{Introduction}

The government has stipulated in Law on Health No. 36 of 2009, Article 101 paragraph (1) states that the community is given the widest opportunity to process, produce, distribute, develop, improve and use traditional medicines that can be accounted for in terms of benefits and safety. Besides, the government guarantees the development and maintenance of raw materials for traditional medicines. Sources of traditional medicines that have been proven efficacious and safe to use in the prevention, treatment, care, and/or maintenance of health are well kept. Regulation of Minister of Health No. 9 of 2016 concerning efforts to develop health through self-care utilization of family herbal plants and cultivation and processing skills provides an opportunity to explore the community's local wisdom to use herbal plants. Self-care health of traditional healing is an effort to maintain and improve health and prevent and overcome minor health problems experienced by individuals, families, groups, and communities by utilizing family herbal plants.

Based on Silalahi's research (2016) Indonesia has 25,000-30,000 species of plants and 300-700 ethnic groups use local plants for various purposes, one of which is for medical treatment. The utilization of local plants is usually passed from mouth to mouth and hereditary so that increases the potential for degradation.

Enggano Island was designated as one of the outermost small islands in Indonesia based on the Presidential Decree of the Republic of Indonesia No. 6 of 2017. It is located in Bengkulu Province, 90 miles from the city of Bengkulu. Administratively, Enggano is part of North Bengkulu regency.

According to LIPI researcher, Hamidy (2015), Enggano Island is an oceanic island and throughout its geological history, this island has never joined the island of Sumatra so that Enggano island has rich biodiversity which is generally endemic on Enggano island and some are unique and rare species. The results of the exploration of LIPI researchers in 2015 revealed that Enggano is rich in the diversity of flora and fauna that are important to preserve. There are more than 16 candidates for new types of flora and fauna which are likely to be typical flora and fauna of Enggano that cannot be found elsewhere. 
The most common diseases found in Enggano sub-district based on data from the top 10 diseases are Acute Respiratory Inspection (ISPA) followed by gastritis and cephalgia, but these data do not represent a real diagnosis because there is data of the disease which is a symptom of the disease rather than a diagnosis of the disease.

Based on data from the North Bengkulu Regency Central Statistics Bureau (2018) the number of health workers on duty in the Enggano sub-district consists of 1 general practitioner, 1 dentist, 11 nurses, 3 midwives, 1 pharmaceutical worker, and 11 health workers to serve the population of 3213 people. These health workers have concentrated in the sub-district city and even general practitioners are rarely in place, so the community complained that it is hard to get health services when they need services, especially in an emergency.

Besides, the Enggano community still holds the customs tradition which is a cultural richness such as the practice of medical treatment that uses local plants in the neighborhood. Community preferences for seeking traditional treatment are also supported because of the limited availability of health workers on duty when needed.

Based on Novira's research (2018) there are still traditional beliefs that persist related to people's perceptions of diseases and ways of treatment. Perihei is still believed to be a health problem when someone is exposed to magical powers so that the treatment also uses non-medical methods. Besides, there are plants that are also often used for the treatment of malaria such as Subang-subang leaves. The fruit of this plant is also believed to cure eyesore.

The endemic biodiversity on the island of Enggano has not yet been fully explored by researchers. The great efficacy of plants for traditional medicine used by the people of Enggano island still needs further study.

The community complained about the difficulty in accessing health services. Health workers, both doctors, and nurses are rarely on-site and are more centralized in the sub-district, such as in the village of Apoho. Those who live in other villages or are far enough from the sub-district experience potentially life-threatening because they need a longer time to reach the health facility. The community needs alternatives in overcoming their health problems including using local plants as medicine in maintaining and recovering their health conditions.

The research question is what local plants are commonly used by the people of Enggano island when they have got sick?

\section{Method}

This study used a qualitative method with an ethnographic approach. The ethnographic approach emphasizes contextual aspects by leaving theoretical assumptions or propositions so that the research is more natural. Data collection was done through observation, in-depth interviews, and documentation studies. The observation was carried out by exploring plants commonly used by local people as medicine. To explore the results of observations in-depth interviews were conducted based on the interview guidelines. In-depth interviews were conducted with informants or research subjects.

The informants in this study were people who have the knowledge and ability to cure diseases using local plants or ingredients and are popular in the community. The informants of this study consisted of key informants and additional informants. Key informants were traditional leaders, mainly Paabuki, the coordinator of all the tribal leaders from 6 (six) clans, namely the Kaitora, the Kauno, the Kaarubi, the Kaharuba, the Kahoao, and the Kamay clans. The chief clan interviewed in this research was the chief of Kamay clan and the local community who regularly use traditional medicine from local ingredients at Enggano Island.

Documentation studies were carried out to complete the data collection process. Researchers conducted documentation studies related to research topics. The documentation study was obtained through the results of other people's research published in scientific journals, textbooks and also by studying profile data about the Enggano island from the local government, North Bengkulu Regency, and data from the sub-district.

Table 1. Informant Description

\begin{tabular}{|c|l|l|c|c|}
\hline No. & $\begin{array}{c}\text { Informants' } \\
\text { Names }\end{array}$ & \multicolumn{1}{|c|}{ Position } & $\begin{array}{c}\text { Age } \\
\text { (year) }\end{array}$ & Education \\
\hline 1. & Mr.HK & Paabuki & 74 & Elementary School \\
\hline 2. & Mr. MR & Chief of Kamay Clan & 53 & Elementary School \\
\hline 3. & Mr.BS & Head of BPD of Kahyapu Village & 39 & Vocational High School \\
\hline 4. & Ms. Yo & Maternal Shaman of Meok Village & 77 & Elementary School \\
\hline 5. & Ms. Ru & Maternal Shaman of Kaana Village & 56 & Elementary School \\
\hline 6. & Ms.Dm & Maternal Shaman of Kahyapu Village & 54 & Elementary School \\
\hline 7. & Ms. Yu & Nurse of Enggano Health Center & 28 & 3-year-Diploma \\
\hline 8. & Mr. Mdi & Native of Meok Village & 40 & Undergraduate \\
\hline 9. & Ms. EY & Native of Kaana Village & 30 & High School \\
\hline 10. & Ms. Ar & Native of Kahyapu Village & 65 & Not school \\
\hline 11. & Ms.Wl & Native of Banjarsari Village & 26 & Elementary School \\
\hline
\end{tabular}

Data analysis used two approaches namely qualitative approach using ethnographic analysis and quantitative 
approach by measuring the Index Cultural significance (ICS). The first stage of the analysis was to describe the results of data collection in chronological order. Researchers did domain analysis, which is a general description of data collection results. The next step was to do a compound analysis. The analysis was done by comparing the differences from the results of data collection. At this stage, some information requires triangulation to other informants or direct assessment in the field. The third stage was ethnographic interpretation or data transformation, in this case, the researchers considered if there are elements that are not appropriate or cause multiple interpretations and doubts for the reader. The researcher also did personalization on the interpretation phase.

\section{Result}

\subsection{Herbal Plants in Enggano Island}

The followings are the herbal plants used regularly by people in Enggano Island .

\begin{tabular}{|l|l|c|}
\hline No. & Name of Herbal Plant & Place of Grow \\
\hline & Subang-subang Leaves (Dihnan) & Seashore \\
\hline & Subang-subang fruit & Seashore \\
\hline & Akar kuning & Woods \\
\hline & White Bahar root & Sea waters \\
\hline & Sagu stem & Backyard \\
\hline & Red Puding & Backyard \\
\hline & Malapari stem & Seashore \\
\hline & Cherry Leaves & Backyard \\
\hline & Tujuh langit Leaves & Woods \\
\hline & Spices: tumeric, temulawak, temu ireng, bitter lempuyang, ginger & Backyard \\
\hline & Betel leaves & Backyard \\
\hline & Root of young Bitternut & Backyard \\
\hline & Pepper root & Backyard /farmland \\
\hline & Cendet root & Paddy field \\
\hline Sembung root & Paddy field \\
\hline Soursop fruit & Backyard \\
\hline & Soursop leaves & Backyard \\
\hline & Meluntas leaves & Backyard \\
\hline & Kemuning & Backyard \\
\hline The young leaves of papaya lanang & Backyard \\
\hline Jarak Leave & Backyard \\
\hline Lemongrass leaves & Backyard \\
\hline & Kucai & Backyard \\
\hline & Dober & Woods \\
\hline & Pruh kiamek leaves & Woods \\
\hline
\end{tabular}

The herbal plants grow at the backyards, woods, farmland and paddy field.

\subsection{Herbal Plants Utilization}

The utilization of herbal plants by the community can be seen in the table below.

Table 3. The Utilization of Herbal Plants

\begin{tabular}{|c|c|c|}
\hline No. & Name of plants & Benefit \\
\hline 1. & Subang-subang Leaves (Dihnan) & For malaria, for laxative \\
\hline 2. & Subang-subang fruit & Eyesore \\
\hline 3. & Akar kuning & For diabetes, hepatitis (yellow eye), and malaria \\
\hline 4. & White Bahar root & Antidote for fish poison \\
\hline 5. & Sagu stem & As baby powder to ease rush \\
\hline 6. & Red Puding & $\begin{array}{l}\text { For sprain, internal wounds, maintaining health for post-natal } \\
\text { women }\end{array}$ \\
\hline 7. & Malapari stem & $\begin{array}{ll}\text { For malaria } \\
\end{array}$ \\
\hline 8. & Cherry Leaves & For diabetes, high cholesterol \\
\hline 9. & Tujuh langit Leaves & unknown \\
\hline 10. & $\begin{array}{l}\text { Spices: turmeric, temulawak, } \\
\text { temuireng, bitter lempuyang, ginger }\end{array}$ & Maintain the stamina \\
\hline 11. & Betel leaves & For spice mixture, reduce body odor potion \\
\hline
\end{tabular}




\begin{tabular}{|l|l|c|}
\hline No. & \multicolumn{1}{|c|}{ Name of plants } & Benefit \\
\hline 12. & Root of young Bitternut & $\begin{array}{c}\text { To maintain the health, clean the internal body after giving } \\
\text { birth }\end{array}$ \\
\hline 13. & Soursop fruit & To heal gout \\
\hline 14. & Soursop leaves & To reduce fever in children \\
\hline 15. & Meluntas leaves & As a tea, for 7-month pregnant women \\
\hline 16. & Jarak leaves & To quench the thirst \\
\hline 17. & Dober & To heal fever in children \\
\hline 18. & Kucai leaves & As herbal drink (jamu) \\
\hline 19. & Kemuning & For malaria \\
\hline 20. & The young leaves of papaya lanang & Mixed with betel leaves and galangal and used as bathing \\
\hline 21. & Lemongrass leaves & To reduce temperature/fever in children \\
\hline 22. & Preh kiamek leaves & red \\
\hline
\end{tabular}

Based on the informants' testimony, herbal plants are commonly used both for the prevention and treatment of disease.

\subsection{Ways to Utilize Herbal Plants}

There were many ways to utilize herbal plants according to the informants as follows:

Subang-subang leaves or called Dihnan in Enggano is used for malaria at a dose of 7-5-3 as conveyed by Mr. Mdi "The first day is 7 leaves, the second day is 5 leaves, the third day is 3 leaves. The leaves are washed clean, pounded, then mixed with warm water, squeezed into half a glass, only take the water. Drink it for 3 days in the morning, at the same time "

Mr. Mdi also said that the cherry plant is used as a medicine for cholesterol and diabetes.

"Cherry shoots are for diabetes and cholesterol, 7 leaves are boiled with two glasses of water, boil it into one glass, drink at night"

The Paabuki, Mr.HK, said that information related to Tujuh langit leaves is as follows:

"The Chinese look for these leaves, but we don't know what's the benefit, the price is expensive, we named it Tujuh langit for its seven-layer leave"

Paabuki advised the research team to persuade the Chinese to tell them the use of Tujuh langit leaves. Right now, the leaf is no longer allowed to be taken by the Chinese, because the community is disappointed not being told of its usefulness.

Other herbal plants that are often used in Enggano are Subang-subang leaves or "Dihnan". This plant is found along the coast of the island of Enggano. The Subang-subang leaves are used by the community as a cure for malaria and cleanse the stomach for the patient with diarrhea. In addition to the leaves, the fruit (the white one) is used by the community as eye drops. Pruh kiamek and Kucai leaves are used to reduce fever for babies and kids. Health center officer states:

"Once, a baby was taken to the health center, we were surprised to see that his body was all green, it was covered with the crushed Kucai leaves ... we asked why, his mother said (the leaves) to reduce the heat"

Another plant that is often used is the white Bahar root that grows in the sea waters. The white Bahar root is used by the community for an antidote to fish poison, while the black Bahar root is used for accessories, such as bracelet and is believed to have magical power, as it told by Ms. EY, the informant, in Kaana village as follows:

"The black Bahar root, the stone, is for reflexology, made into a bracelet, the stone sticks to the skin to improve blood circulation, in the past, it is related to magical"

Another herbal plant is Akar kuning used mainly to cure hepatitis, besides malaria and diabetes. Meluntas leaf is to heal injured or loose nails.

The plants used by the Enggano island community are not only for medicine but also for maintaining health and increasing stamina.

The plants used for medicine are processed in various ways, some are squeezed and then the juice content is taken, boiled, shredded and then boiled, some are ground and then filtered, some are directly used to get the juice from the stems.

The use of Akar kuning is for hepatitis, diabetes and some say that it is used for malaria. Different informants conveyed different benefits of herbal plants. One of the informants, Ms. Ew said that Akar kuning is for diabetes. "Akar kuning is peeled, the insides are boiled, drink the water, just as needed, there are not fix doses" Meanwhile, Mr. Mdi said that Akar kuning is for malaria.

"Akar kuning is boiled for malaria, cut about seven parts, boiled with two glasses of water into one glass, drink the water"

Mr. HK, a paabuki, the coordinator of the clan chiefs, said that Akar kuning is to cure hepatitis. 
"Akar kuning is boiled with two glasses of water into one glass, drink the water to cure hepatitis and prevent liver failure"

Mr. HK also told the use of Kiamek pruh leaves, Subang-subang fruit and Malapari stems as medicine.

"Choose the white rip fruit, squeeze the juice into a sore eye. Pruh kiamek leaves are used to prevent the bleeding in the wound, just apply (the leaves) to the wound. For Malapari stem, scrape off the flesh and then add a little water, drink the water for the bloated stomach"

The chief of Kamay clan also said that young soursop fruit and soursop leaves are useful for medicine.

"Shred young soursop fruit then squeeze, drink the water. Drink it for gout, once a day until it is recovered. For the leaves, squeeze them, add some water and drink as needed to relieve fever in children"

\subsection{Herbal Plants for Health Maintaining}

Herbal plants in Enggano island are not only used for medication but also to maintain health or maintain stamina, as the informants said as follows:

"Black bahar root is for blood circulation when applied to the skin, the stone is for reflection" (Ms. EY)

"Dober stems are usually used when (people) going to the forest, when they get thirsty, cut the stem in a slanted position, drink the juice that comes up as drinking water" (Mr. Mdi)

"There are 40 types of plants and herbs, I can't remember all the names, there are green coconut roots, young bitternut roots, brotowali, temulawak, temu ireng, turmeric, rumput dukung anak, kates lanang roots, cicendet stems ... all dried in the sun, take some, boil with five glasses of water into two glasses, drink the water once a day until the body feels better "(Ms. Ru)

Maternal Shaman, Ms. Yo, lives in the village of Meok using several plants to maintain the stamina of the mother after giving birth and caring for the baby.

"... turmeric, kencur, ginger, bitter lempuyang, sirih leaves, young bitternut, mixed all, boil. For red pudding leaves, add palm sugar, milk and eggs, drink it every day after giving birth. The herb is to reduce body odor, bitter lempuyang can ease constipation. Sagu stems are used as baby powder, grate the tubers, squeeze the water out, precipitate and dry. This is used to keep the baby's skin out of rush. Jarak leaves can also be made as tea, dry one leaf, brewed, drink along the seven months of pregnancy to maintain maternal health "

\subsection{Index Cultural Significance (ICS) of Herbal Plants}

The following results are the ICS scoring results of plants used for medicine and maintain the health in Enggano District (see table 4.3).

Table 4. ICS of Herbal Plants

\begin{tabular}{|c|l|c|}
\hline No. & \multicolumn{1}{|c|}{ Name of Plants } & ICS Score \\
\hline 1. & Subang-subang leaves (Dihnan) & 30 \\
\hline 2. & Subang-subang fruit & 18 \\
\hline 3. & Akar kuning & 9 \\
\hline 4. & White Bahar roots & 24 \\
\hline 5. & Sagu stem & 24 \\
\hline 6. & Red Puding & 9 \\
\hline 7. & Malapari stem & 16 \\
\hline 8. & Cherry leaves & 8 \\
\hline 9. & Spices: turmeric, temulawak, temu ireng, bitter lempuyang, ginger, kencur & 9 \\
\hline 10. & Sirih leaves & 18 \\
\hline 11. & Young bitternut roots, sahang roots, cendet roots, sembung roots & 9 \\
\hline 12. & Soursop fruit & 12 \\
\hline 13. & Soursop leaves & 6 \\
\hline 14. & Meluntas leaves & 12 \\
\hline 15. & Jarak leaves & 18 \\
\hline 16. & Dober & 24 \\
\hline 17. & Kucai leaves & 12 \\
\hline 18. & Kemuning & 6 \\
\hline 19. & Kates lanang shoots & 12 \\
\hline 20. & Lemongrass & 9 \\
\hline 21. & Pruh kiamek leaves & 9 \\
\hline 22. & Tujuh langit leaves & 1 \\
\hline
\end{tabular}

In table 4 above, Subang-subang leaves got the highest ICS score of 30 then followed by white Bahar roots, Sagu stems, and Dober with a score of 24. Score 18 was for Subang-subang fruit, Sirih leaves and Jarak leaves. Tujuh langit leaves got the smallest ICS score because the communities do not know the benefit, even though the 
Chinese often look for these leaves.

\section{Discussion}

\subsection{Herbal Plants in Enggano Island}

Based on table 3.1 above, it can be seen that most of the plants commonly used by the Enggano community were also often used by people in other areas both in Bengkulu Province and outside Bengkulu Province such as betel leaves, soursop fruit, soursop leaves, sagu stems, cherry leaves, some roots such as ginger, temu ireng, temu lawak and turmeric.

Local plants were plants that grow in people's homes or in the area that are commonly used from generation to generation, it was also possible to grow in other areas with different names taken from the local languages and different ways to process them according to local customs or culture. This was in line with Rohyani's research (2014).

Enggano indigenous people had mingled with migrant communities so that the culture brought by migrants was well received by the Enggano community, and vice versa migrant communities adapted to the culture of native Enggano. Kahyapu villagers is occupied by migrants from Java, Madura, and communities from other districts in Bengkulu Province.

There were plants that had not been known their benefit but many migrants like the Chinese community looked for the leaves of Tujuh langit. Based on the investigation obtained by the researchers about Tujuh langit leaves, there was a plant found with the same characteristics but with a different name, "Tunjuk langit" (Hartini, 2011). The benefit of this plant, especially its roots, is for cancer, while its leaves contain antioxidants and are for skin rejuvenation.

The typical plant that grows on the seashore was Subang-subang or Dihnan in Enggano language. People used it as an anti-malaria drug, although there were alternatives such as Akar kuning and Malapari. The most common use was Subang-subang leaves, while Akar kuning was more widely used as anti-hepatitis and diabetes mellitus.

\subsection{Utilization of Herbal Plants}

Society used medicinal plants in various ways, shredded, the scrapped bark of plants, crushed, ground, boiled, applied directly, mixed with several other plants as a potion. The ways to process the herbal plants were based on the hereditary habits of parents and grandparents. People used herbal plants as the first aid and if they did not recover they sought treatment at a health facility.

Local plants in this study did not mean the plants that only grow on Enggano Island. There were some plants commonly used by people outside of Enggano Island such as betel leaves, cherry, rhizomes as spices or herbal potion such as turmeric, kencur, ginger that have been planted and utilized by the local community. Some plants grow in the forest without being planted or cultivated by the community.

\subsection{Utilization of Plants for Health Maintaining}

Based on the information from the informants, herbal plants grown on the island of Enggano were commonly used for medicine and also for maintaining health, but the benefits of these plants were unknown and the active ingredients are not proven scientifically, only empirically used by the community. The benefits of plants that are not known by the public are Tujuh langit leaves.

The use of herbal plants to maintain the health and stamina in the community was based on the knowledge passed on by parents.

\subsection{Index Cultural Significance}

Based on the ICS scoring results Subang-subang leaves got the highest score of 30 and Tujuh langit leaves got the lowest score of 1 . This scoring only showed the usefulness or benefits of plants by the local community, it did not indicate the content of plant parts as it was mentioned in Helida's study (2015). Tujuh langit got the lowest score of 1 based on the calculation of the quality of use (q) that means the community knew the plant, the intensity of use (i) was very rare because it was rarely even utilized due to people did not know its benefits, and the exclusivity score (e) there were several possibilities related to the efficacy of plants. The low score did not mean that the plant was not useful, because ICS only showed the cultural utilization of plants, habits and empirical experiences of the use in the community (Basir, 2015). In line with Hartini's research (2011) Tujuh langit plant (Tunjuk langit) is a kind of terrestrial fern and the Chinese used its tuber called gong wu di. The roots of Tujuh Langit was used as a stimulant or anti-impotence and anti-cancer. So, according to the coordinator of the chiefs, Paabuki, many Chinese hunted for Tujuh Langit plants for medicine but they kept the benefit as a secret.

\section{Conclusion}

Based on the research it can be concluded as follow: 
a) Some of the plants used as a medicine on Enggano island by the local community had been documented.

b) The ways to utilize the plants were by scraping off the bark, pounding, boiling, kneading, drying or using the part of the plants directly. Some plants were used individually and others are mixed with other plants

c) The plant with the highest Index Cultural Significance was the leaf of Subang-subang or Dihnan while the lowest was Tujuh langit leaves. The low ICS score is due to people's ignorance of its usefulness.

6. Reference

Agrippina,Melda.(2015), Sumber Daya Genetik Pulau Enggano. https://www.academia.edu/31107321/SUMBER_DAYA_GENETIK_ENGGANO_2015

Basir,Abdul,dkk. (2015). Mengukur Kepentingan Budaya Dari Sumber Daya Hutan Melalui Kajian Etnobotani Kuantitatif. Jurnal Teknologi Pertanian Universitas Mulawarman, vol 10(1): p.8-17

Dwisatyanindi,Multimanda. (2017), Pemanfaatan Tanaman Obat untuk Pencegahan dan Pengobatan Penyakit Degeneratif. [online] Avaiable http://repository.ut.ac.id/7079/1/UTFMIPA2017-10-mutimanda.pdf 18 Februari,13.55

Febriyanti,Alifia Putri; Iswarin,Siti Jazima; Pariwara,Praditya Widya. (2016), Identifikasi dan Eksplorasi Etnomedisina pada Suku Samin di Kabupaten Bojonegoro Jawa Timur. Journal of Pharmaceutical and Medical Sciences.vol.1(2).p.69-74

Hamidy,Amir. (2015), Mengenal Spesies Flora dan Fauna Langka di Enggano. [online] Available 10 Nov 2015http://lipi.go.id/lipimedia/mengenal-spesies-flora-fauna-langka-dari-enggano/10582 16 Jan 2019,09.05

Hartini,Sri. (2011), Helminthostachys zeylanica (L): Potensinya sebagai obat masa depan. Pusat Konservasi Tumbuhan Kebun Raya Bogor LIPI.

Helida,Asvic. (2015), Index of Cultural Significance as a Potential Tool for Conservation of Plants Diversity by Communities in the Kerinci Seblat National Park. JMHT. vol.21(3).p 192-201.Dec.2015.

Jimung,Martinus.(2017), Antropologi Kesehatan Konsep dan Aplikasi. Jakarta : Trans Info Media

Kaur,Mandeep; Vashistha,B.D. (2018), Cultural importance indices of some useful plants of Ambala District, Haryana,India. Academia Journal of Medicine Plants. vol 6(6);p.127-132.

Kim,Hyun;Jang song-Mi;Brian,Heldenbriand; Choi,Kyoungho (2014), A Comparative Analysis of Ethnomediscinal Practices for Treating Gastrointestinal Disorders Used by Communities Living in Three National Park (Korea). Evidence Based Complimentary and Alternative Medicine.vol 2104. 17 August 2014. p.1-31.

Lesmana,Hendy,dkk.(2018). Pengobatan Tradisional Pada Masyarakat Tidung Kota Tarakan : Studi Kualitatif Kearifan Lokal Bidang Kesehatan. Medisains: Jurnal Ilmu-Ilmu Kesehatan vol.16(1). April 2018.

LIPI.(2015), Mengenal Spesies Flora dan Fauna Langka di Pulau Enggano. [online] Available http://lipi.go.id/lipimedia/mengenal-spesies-flora-fauna-langka-dari-enggano/10582;16 Januari 2019,09.05

Mujahid,Rohmat; Nurindra,Rohmansyah W; Yanuar,Firda.(2017), Eksplorasi Pengetahuan Lokal Etnomedisin dan Tumbuhan Obat Berbasis Komunitas di Indonesia. Jakarta: Balai Besar Penelitian dan Pengembangan Tanaman Obat dan Obat Tradisional Balitbang Kemenkes RI.

Neuman,W.Lawrence. (2014), Social Research Methods : Qualitative and Quantitative Approaches. $7^{\text {th }}$ edition. USA: Pearson Education Limited

Ningsih,Indah Yulia.(2016), Studi Etnofarmasi Penggunaan Tumbuhan Obat oleh Suku Tengger di Kabupaten Lumajang dan Malang Jawa Timur. Jurnal Pharmacy. vol.13(01) Juli 2016.p.10-20

Novira, Daisy.(2019), Local Genius of Engganese Community in Bengkulu Province (An ethnographic study of health and illness perception). Research on Humanities and Social Sciences. vol.9(4). 2019.p.41-48.

Pandey,Prabhat; Pandey,Meenu Mishra.(2015), Research Methodology: Tools and Technique. Romania: Bridge Center.

Permawani,Popi;Kurniasih,Fadillah;Saputro,Martono Hadi.(2018), Kabupaten Bengkulu Utara Dalam Angka 2018. Bengkulu: Biro Pusat Statistik Bengkulu Utara.

Rohyani,Immy Suci dkk.(2014), Potensi Tumbuhan Lokal Pulau Lombok dalam Upaya Menunjang Ketahanan Pangan. Prosiding. ISBN:978-602-14432-2-4.Seminar Nasional Pendidikan STKIP Surya. Tangerang.p.256264.

Quinlan,Marsha B. (2011), Ethnomedicine in A Companion to Medical Anthropology (ed). p.381-403. UK:Willey-Blackwell

Staub,Peter O; Geck,Mathias; Weckerle,Caroline S; Casu,Laura; Leonti,Marco.(2015), Classifying Diseases and Remedies in Ethnomedicine and Ethnopfarmacology. Journal of Ethnopharmacology. http://dx.doi.org/10.1016/j.jep.2015.08.051

Silalahi,Marina.(2016), Studi Etnomedisin di Indonesia dan Pendekatan Penelitiannya. JDP. Vol.9(3). November 2016;p.117-124

Silalahi,Marina.(2018), Etnomedisin Tumbuhan Obat oleh Subetnis Batak Pakphak di Desa Surung Mersada, Kabupaten Pakphak Barat Sumatera Utara. Jurnal Ilmu Dasar. vol 19(2).Juli 2018.p.77-92. 
Suharjito,D.et al.(2016), Comparing Medicinal Plants Use for Traditional and Modern Herbal Medicine in Long Nah Village of East Kalimantan.Bionatura-Jurnal Ilmu-ilmu Hayati dan Fisik. vol.16(2). Juli 2016.p.95-102 Swandari,Paramita.et al.(2017), Anti inflammatory activities of Ethnomedicinal Plants from Dayak Abai in North Kalimantan Indonesia. Biodiversitas.vol.18(4).November 2017.p.1556-1561.

Tumpa,Sanjida Islam;Hossain,Md.Iqbal; Ishika,Tashneema.(2014), Ethnomedicinal uses of Herbs by indigineous practitioner of Jennaidah district, Bangladesh. Journal of Pharmacognosy and Phytochemistry. vol.3(2).p.2333.

Wijaya,Hengky.(2018), Analisis Data Kualitatif Model Spradley (Etnografi). Article,March [online] Available http://reserachgate,net/publication/323557072 